\title{
SUHTEETONTA ELÄMÄÄ - PARISUHTEETTOMIEN ONNELLISUUSTEKIJÄT
}

\author{
Anu Kinnunen: nuorempi tutkija, Tampereen yliopisto \\ Osmo Kontula: VTT, tutkimusprofessori, Väestöliitto
}

anu.kinnunen@tuni.fi; osmo.kontula@vaestoliitto.fi

Janus vol. 29 (2) 2021,141-159
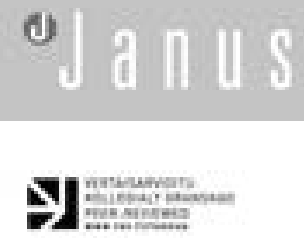

\section{Tiivistelmä}

Tässä tutkimuksessa selvitetään parisuhteettomien miesten ja naisten onnellisuuteen yhteydessä olevia tekijöitä ja tarkastellaan, kuinka onnellisuus kytkeytyy intiimisuhteisiin, yksinäisyyden kokemukseen, liikunnallisuuteen, alkoholin käyttöön, uskonnollisuuteen, terveyteen ja sosioekonomiseen asemaan. Aineistona käytetään FINSEX-kyselyn parisuhteettomien vastauksia ( $N=944)$ ja menetelmänä binääristä logistista regressioanalyysï sekä ristiintaulukointia. Kysymme, eroavatko parisuhteettomat miehet ja naiset toisistaan onnellisuuden ja onnellisuuteen yhteydessä olevien tekijöiden suhteen. Tulokset osoittavat, että parisuhteettomat naiset ovat keskimäärin parisuhteettomia miehiä onnellisempia. Miehet raportoivat naisia useammin, että kumppanin löytäminen sitä kaivattaessa on vaikeaa. Parisuhteettomien naisten onnellisuus on vahvasti yhteydessä vähäiseen koettuun yksinäisyyteen. Parisuhteettomien miesten onnellisuutta puolestaan ennustavat voimakkaimmin vähäiset psykosomaattiset oireet ja liikunnallisuus.

\section{JOHDANTO}

Suomi on väestökyselyiden perusteella yksi maailman onnellisimmista maista (Helliwell ym. 2020). Suomessa on kuitenkin väestöryhmiä, jotka kokevat itsensä muita onnettomammiksi. Onnellisuutta mitataan monin eri tavoin. Suppeimmillaan ihmisen voidaan katsoa olevan onnellinen, mikäli hän on itse tyytyväinen elämäänsä. World Happiness Reportia varten kysytään subjektiivista arviota (asteikolla 1-10) siitä, kuinka lähellä oma elämä on parasta mahdollista elämää (Helliwell ym. 2020). Laajemmin tulkittuna ihminen ei voisi olla onnellinen, mikäli onnelle ei ole todellista oikeutusta. Tällainen onnellisuuskäsitys pitää sisällään onnellisuuden edellytyksinä sekä ympä- ristöön että henkilön omiin kykyihin, kuten mielenterveyteen, liittyviä tekijöitä (Veenhoven 2013).

Monissa onnellisuutta tarkastelevissa tutkimuksissa avio- tai avoliitossa asuvat ovat yksin asuvia onnellisempia ja sosiaaliset suhteet näyttäytyvät keskeisenä onnellisuuden lähteenä (Diener \& Saligman 2002; Kainulainen 2014; Saarinen ym. 2013; Kontula 2011; Kontula \& Saari 2016). Anne Birgitta Pessin (2008) mukaan perhe on tärkein onnellisuuden lähde, terveyden ja rakkauden seuratessa toisena ja kolmantena. Näiden jälkeen onnellisuutta tuottavat ystävät ja vakaat tulot. Parisuhteella on keskeinen merkitys ihmisten koetun onnellisuuden ja elämään tyytyväisyyden rakentajana eri- 
tyisesti korkean elintason maissa (Richmond \& Roehner 2017). Merkitys on aikaisemman tutkimustiedon mukaan erityisen suuri juuri Pohjoismaissa, sillä hyvinvointivaltioissa arvostetaan ihmissuhteita ja postmaterialistisia arvoja onnellisuuden lähteinä enemmän kuin tuloja tai omaisuutta (Saari 2012).

Parisuhteen merkitystä onnellisuuden lähteenä tukee teoria, jonka mukaan ihmisellä on perustarve kuulua joukkoon (Baumeister \& Leary 1995). Teorian mukaan on keskeistä, että tekemisissä ollaan usein, kohtaamiset toistuvat saman henkilön kanssa, ja ovat emotionaalisesti miellyttäviä sisältäen tunteen yhteydestä. Tiedetään myös, että hylätyksi tuleminen vähentää itsekeskeistä ajattelutapaa (Knowles 2014). Avio- tai avoliiton solmimisen myötä täyttyy myös normatiivinen parisuhdeolettama, mikä voi osaltaan lisätä hyvinvointia (Musick \& Bumpass 2012).

Parisuhteessa olevien vertaaminen parisuhteettomiin on kuitenkin ongelmallista, koska parisuhteeseen valikoituminen ei ole sattumanvaraista. On esimerkiksi esitetty, että onnelliset ihmiset valikoituvat parisuhteisiin ja naimisiin onnettomia helpommin (Stack 1998). Itsensä parisuhteessa onnettomaksi kokevat eroavat helpommin ja parantavat näin osaltaan parisuhteellisten onnellisuusprosenttia. Äskettäin vasten tahtoaan eronneet tai leskeksi jääneet eivät todennäköisesti ole kovin onnellisia. Tämä aiheuttaa parisuhteettomien ja parisuhteessa elävien vertailuun väkisinkin parisuhdeonnea korostavaa vääristymää, jota on vaikea huomioida tuloksia tulkittaessa (DePaulo 2014).
Tämä tutkimus selvittää onnellisuuteen yhteydessä olevia tekijöitä tilanteessa, jossa vakituista parisuhdetta ei ole. Käytettävissä olevasta FINSEX-aineistosta on poimittu mukaan muuttujia, joilla on aikaisemmissa tutkimuksissa havaittu yhteys onnellisuuteen. Tällaisia tekijöitä ovat: yksinäisyys (Cacioppo ym. 2006), intiimisuhteet (Blanchflower \& Oswald 2004), liikunnallisuus (Huang \& Humphreys 2012), alkoholin käyttö (Koivumaa-Honkanen ym. 2012), uskonnollisuus (Van Cappellen ym. 2016), terveys (psykosomaattiset oireet) (Sun ym. 2016) ja sosioekonominen asema (tulot, työelämään sijoittuminen) (Berlin \& Kaunitz 2015). Miehiä ja naisia tarkastellaan erikseen, koska aikaisemmissa tutkimuksissa on tullut esille onnellisuuden sukupuolisidonnaisuus ja parisuhdestatuksen erilainen vaikutus onnellisuuteen miehillä ja naisilla (Solé-Auró ym. 2018; Stavrova ym. 2011).

Aiempi parisuhteettomuutta koskeva tutkimus perustuu pääsääntöisesti haastatteluaineistoihin, ja kohderyhmänä on ollut vain joko miehet tai naiset (Budgeon 2008; Hostetler 2012; Lewis \& Moon 1997; Reynolds ym. 2007). Nyt tehtävä tutkimus avaa parisuhteettomuuden kokemuksen mahdollista sukupuolittuneisuutta ja tarjoaa lisää ymmärrystä parisuhteettomien onnellisuuden ja siihen kytkeytyvän hyvinvoinnin ymmärtämiseen.

\section{Parisuhteettomien kasvava joukKo}

Parisuhteellisten osuus Suomen väestössä on vähentynyt viimeisen viidentoista vuoden aikana. Kehityskulun taustalla ei kuitenkaan ole havaittavis- 
sa yksinelämistoiveiden samanaikaista lisääntymistä (Kinnunen \& Kontula 2018). Pikemminkin sen taustalla vaikuttavat jo pitkään jatkunut nuoruusajan pidentyminen ilman vakituista kumppania, ikääntyvien parisuhteettomien määrän kasvu (SVT 2020), avoja avioerojen yleisyys (SVT 2019) sekä lisääntyneet toiveet niin potentiaalista kumppania kuin parisuhteen laatua kohtaan (Maksimainen 2014). Tässä tilanteessa on erityisen tärkeää sekä tutkijoiden että päättäjien ymmärtää tämän kasvavan väestöryhmän erityistarpeita.

Kaikki parisuhteettomat eivät asu yksin ja kaikki yksinasuvat eivät ole parisuhteettomia. Paremman tilastoinnin puuttuessa voidaan yksinasumisen kasvun nähdä heijastavan myös parisuhteettomuuden kasvua ja katkonaisuutta tai etäisyyden lisääntymistä parisuhteissa niin, että kumppanit asuvat yhä useammin toisistaan erillään. Koko Euroopan laajuisesti yksinasuvien osuus väestöstä kasvaa (Eurostat 2019). Suomessa yksinasuvien määrä on eurooppalaisittain korkea: kotitalouksista yhden hengen talouksia oli vuonna 2019 lähes 45 prosenttia (SVT 2020), kun koko Euroopan keskiarvo (vuonna 2017) oli 32 prosenttia (Eurostat 2019).Vain Norjassa ja Tanskassa yksinasuminen on yleisempää kuin Suomessa (Eurostat 2019).

Parisuhteettomuuden lisäksi, yksinäisyys on noussut viime aikoina poliittiseksi teemaksi ja saanut sen myötä paljon mediajulkisuutta. Yksinäisyyttä kokevia löytyy kaikista ikäryhmistä, aikuisväestössä yksinäisyyden kokemukset ovat yleisimpiä alle 30-vuotiailla ja yli 70-vuotiailla. (Junttila 2015; Sini ym. 2015.) Yksinasuvien keskuudessa nuoret kokevat eniten yksinäisyyttä, keski-ikäisten ja eläkeikäisten kohdalla yksinäisyyttä kokevien osuudet vähenevät, mutta sosiaalinen eristyneisyys lisääntyy. Keski-ikäisistä yksinasuvista viidennes tapaa tuttaviaan harvemmin kuin kerran kuussa. Miesten kohdalla eristäytyneisyys on naisia yleisempää. (Terämä ym. 2018.) Yksinäisyyden on todettu heikentävän niin psyykkistä kuin fyysistäkin terveyttä (Müller \& Lehtonen 2016). Yksinäisyys on yhteydessä koettuun hyvinvointiin yhtä voimakkaasti kuin sosioekonomisista muuttujista esimerkiksi tulot, työllisyys, koulutus ja varallisuus (Junttila ym. 2015).Yksinäisyys voidaan nähdä yhtenä sosiaalisen epätasa-arvon muodoista, sillä se heikentää kokonaisvaltaista hyvinvointia ja voi johtaa pienempiin tuloihin, heikompaan koulutukseen ja hankaluuteen työllistyä. Mekanismin taustalla voivat vaikuttaa yksinäisyyteen usein yhteydessä olevat tekijät, kuten aloitekyvyttömyys, masennus ja eristäytyneisyys (Junttila ym. 2015).

Parisuhteettomat ovat erityisen haavoittuvia yksinäisyyden kokemukselle (Kontula \& Saari 2016), joten vastentahtoinen parisuhteettomuus tulisi huomioida myös yhteiskuntapoliittisena kysymyksenä ihmisten kohtaamattomuudesta.

Aikaisemman tutkimuksen perusteella tiedetään, että naisten kokema yksinäisyys on tyypiltään miehï useammin sosiaalista yksinäisyyttä, eli sosiaalinen verkosto on heikko eikä koeta kuuluvan mihinkään ryhmään. Miehet puolestaan kokevat naisia useammin emotionaalista yksinäisyyttä, joka kertoo läheisten luottamuksellisten ihmissuhteiden puutteesta (Junttila ym. 2015). 
Yksi aikamme merkittävimmistä onnellisuuden tutkijoista Edward Diener muistuttaakin, että on tärkeää tehdä töitä sosiaalisten taitojen, läheisten ihmissuhteiden ja sosiaalisen tukiverkoston eteen, jotta voisi olla onnellinen (Diener \& Oishi 2005). Yhteiskunnallisella päätöksenteolla voidaan vaikuttaa ihmisten onnellisuuteen ja siksi onkin tärkeää ymmärtää, miten eri väestönryhmien onnellisuus rakentuu (Kangas 2010).

\section{MONENLAISET PARISUHTEETTOMAT JA ONNELLISUUS}

Ilman parisuhdetta elämiseen on monia erilaisia polkuja. Avio- ja avoerot, seurustelusuhteiden päättymiset ja kumppanin kuolema ovat osasyitä. Parisuhteettomilla voi olla kokemuksia aikaisemmista suhteista, yhdessä asumisesta tai lapsia, mutta välttämättä ei mitään näistä. Kaikille sitä ensimmäistäkään kumppania ei ole löytynyt. $\mathrm{Pa}$ risuhteettomuuteen voivat kytkeytyä myös lasten hankintaan, isyyteen ja äitiyteen tai siitä luopumiseen liittyvät asiat. On myös niitä, jotka viihtyvät yksin eivätkä toivokaan vakituista suhdetta.

Parisuhdestatuksen moniulotteisuutta kuvastaa se, että kaikki parisuhteessa elävät eivät kuitenkaan ole avoliitossa tai naimisissa eivätkä kaikki parisuhteettomat asu yksin. Rekisteriaineistoihin pohjaava tutkimus ei pysty tunnistamaan moninaisia elämäntilanteita, eikä näin anna parisuhteettomien tilanteesta täysin kattavaa kuvaa. Parisuhteella tarkoitetaan tässä tutkimuksessa suhdetta, johon liittyy luonteeltaan vakituinen intiimisuhde. Parisuhde voi siis olla avioliitto, avoliitto tai muu va- kituinen seurustelusuhde. Parisuhteessa olevista suuri osa asuu kumppaninsa kanssa yhdessä. Tässä tutkimuksessa käytetty aineisto antaa meille mahdollisuuden lukea parisuhteellisiksi myös LAT (living appart together) suhteet ja vakituiset seurustelusuhteet ja näin voimme tarkastella täsmällisesti aidosti parisuhteettomia laajemman yksinasuvien joukon sijaan.

Yhteiskunnassa vallitsevat kulttuurisidonnaiset odotukset esimerkiksi taloudellisen menestyksen, itsenäisyyden ja perhekeskeisyyden suhteen vaikuttavat osaltaan parisuhteettomien hyvinvointiin (Lun \& Bond 2016). Ajatus siitä, että asumisen tulisi aikuisiällä tapahtua kumppanin kanssa yhdessä, voi olla parisuhteettomalle hankala (Lahad 2017). Osa ihmisistä haluaa olla ilman parisuhdetta tai elää vähemmän perinteisissä parisuhdemalleissa. Parisuhteettomuuden ja yksin elämisen tutkimukseen keskittyneen brittisosiologi Roona Simpsonin ilman kumppania eläviä naisia koskevassa tutkimuksessa (Simpson 2016) todetaan, että mikäli parisuhteettomuus ei ole oma valinta, voi tilanteeseen liittyä ulkopuolisuuden tuntemuksia. Tutkimuksen naiset kokivat myös tarvetta selitellä omaa tilannettaan poikkeamana yleisestä parisuhdenormista.

Parisuhteettomien onnellisuutta selittävät todennäköisesti monet samat tekijät kuin parisuhteellisten kohdalla. On kuitenkin syytä olettaa, että ilman parisuhdetta elävien onnellisuutta selittävien tekijöiden lista poikkeaa jossain määrin parisuhteellisista. Esimerkiksi onnellisuuteen helposti yhdistettävä rakkauden kokeminen liittyy usein vakinaiseen parisuhteeseen 
(Kontula 2011). Parisuhteettomilla on myös muita harvemmin läheiseksi koettu perhe tai omia lapsia. Myös henkisen/psyykkisen hyvinvoinnin ongelmat saattavat vaikuttaa parisuhteettomien onnellisuuskokemuksiin parisuhteellisia enemmän. Esimerkiksi ilman parisuhdetta elävillä miehillä on parisuhteellisia miehï enemmän psykosomaattista oireilua ja yksinäisyyttä (Kinnunen \& Kontula 2018).

Parisuhteettomien onnellisuutta tukevat itsenäisyyden luomat mahdollisuudet, kuten vapaus päättää itsenäisesti omasta ajankäytöstä, mutta haastavat yksinäisyyden kokemukset. Väestötasolla onnellisuuden tiedetään olevan yhteydessä sekä fyysiseen terveyteen että mielenterveyteen. Onnellisuuden on havaittu olevan yhteydessä terveyteen niin, että terveys lisää onnellisuutta ja onnellisuus terveyttä (Bjørnskov 2008; Kageyama 2012; Ngamaba ym. 2017; Saarinen ym. 2013). Aiemmassa tutkimuksessa on todettu, että terveyteen liittyvät hyvinvointivajeet ovat parisuhteettomilla miehillä yhteydessä kumppanin toivomiseen ja että parisuhteettomista miehistä vähiten psykosomaattisia oireita kokivat ne, jotka suhtautuivat elämään ilman kumppania positiivisesti (Kinnunen \& Kontula 2018).

Amerikkalaistutkimuksessa on todettu seksuaalisen aktiivisuuden olevan positiivisesti yhteydessä onnellisuuteen (Blanchflower \& Oswald 2004). Suomessa parisuhteessa elävillä on ilman vakituista kumppania eläviä enemmän seksiä ja pariskunnilla säännöllinen seksielämä ennustaa pitkää parisuhdetta (Kontula 2016). Ajankäyttötutkimuksissa on osoitettu intiimin kanssakäymi- sen tärkeys naisille. Intiimi kanssakäyminen oli naisille eniten onnellisuutta tuottava yksittäinen aktiviteetti (Kahneman ym. 2004). Aikaisemman tutkimuksen perusteella tiedetään myös naisten seksuaalisen halukkuuden laskevan iän myötä miehï nopeammin (Beutel ym. 2008).

Aikaisemman tutkimuksen pohjalta herääkin kysymys, miten parisuhteettomien onnellisuus rakentuu. Tässä tutkimuksessa kysymme, kuinka työikäisten parisuhteettomien miesten ja naisten onnellisuus kytkeytyy aikaisemmassa tutkimuksessa onnellisuuteen yhteydessä oleviin tekijöihin: intiimisuhteisiin, yksinäisyyden kokemukseen, liikunnallisuuteen, alkoholin käyttöön, uskonnollisuuteen, terveyteen ja sosioekonomiseen asemaan.

\section{Aineisto ja menetelmät}

Tutkimuksen aineistona käytetään FINSEX-hankkeessa kerättyä suomalaisten seksuaalisuutta, asenteita ja käyttäytymistä kartoittavaa FINSEXpoikkileikkausaineistoa vuosilta 1992 , 1999, 2007 ja 2015 (Sievers ym. 1974; Haavio-Mannila ym. 2001; Kontula 2008; Kontula 2016). Aineisto koostuu 6159 vastauksesta, joista 944 on ilman vakituista parisuhdetta eläviltä. Parisuhteettomien osuus on vastaajissa ollut nouseva ollen 14,1 prosenttia vuonna 1992 ja 18,4 prosenttia vuonna 2015. Aineistossa parisuhteettomat on kuitenkin yhdistetty, jotta saadaan tarkasteltua luotettavasti muuttujien eri luokkia. Parisuhteettomissa oli 519 naista ja 425 miestä.Aineiston tarkempi kuvaus on esitelty aikaisemman artik- 
kelin yhteydessä (Kinnunen \& Kontula 2018).

Kyselylomake sisältää kaikkiaan 127 kysymystä, joista osassa on myös alakohtia. Kysymykset ovat pysyneet pääpiirteissään samoina vuodesta toiseen. Nyt tehtävässä analyysissä käytetään vain osaa vastauksista ja keskitytään tarkastelemaan työikäisiä, 25-64 vuotiaiden ikäryhmää. Eläkeikäisillä arki poikkeaa merkittävästi muusta aikuisväestöstä ja nuorempien kohdalla parisuhdetilanteet ja toiveet vaihtelevat vielä paljon. Nuoruudessa parisuhteettomuus on myös yleisempää kuin vanhempana ja siten kulttuurisesti hyväksytympää. Tässä tutkimuksessa ei tarkastella erikseen seksuaalista suuntautuneisuutta, joskin aineistossa on sekä homo- että heteroseksuaaleja vastaajia.

Onnellisuus on subjektiivinen kokemus. Toisin sanoen jokainen määrittelee itse sen, mistä hänen oma onnellisuutensa koostuu. Yksinkertaisimmillaan onnellisuutta voidaan tiedustella suoraan, kuinka onnelliseksi vastaaja on tuntenut itsenä jonakin aikana. Onnellisuuden syyt voivat olla hyvinkin erilaisia liittyen mielihyvän kokemuksiin, osallisuuden tunteeseen tai laajempaan merkityksellisyyden kokemukseen. Vaihtoehtoisesti onnellisuutta voidaan tutkia kysymyksellä tyytyväisyydestä elämään kokonaisuudessaan tai yhdistelemällä erilaisia koetun hyvinvoinnin ulottuvuuksia. Lomakkeessa onnellisuutta oli mitattu kysymyksellä: "Millainen on elämäntilanteenne juuri nyt?” Kysymyksen viittaus elämäntilanteeseen antaa selvän ohjeistuksen, että vastaajan tulisi ajatella nykyistä elämäntilannettaan kuvaavaa onnellisuutta eikä hetkellistä emotionaaliseen tilaan liittyvää onnellisuutta. Vastausvaihtoehdot olivat: "hyvin onnellinen", "melko onnellinen", "ei onnellinen eikä onneton", "melko onneton" ja "hyvin onneton". Analyysejä varten luokkia yhdistettiin seuraavasti: "hyvin onnellinen" ja "melko onnellinen" yhdistettiin luokaksi "onnellinen" ja "ei onnellinen eikä onneton", "melko onneton" ja "hyvin onneton" yhdistettiin luokaksi "onneton".

Tarkasteltaviksi selittäviksi muuttujiksi valittiin yksinäisyys, intiimisuhteet, liikunnallisuus, alkoholin käyttö, uskonnollisuus, psykosomaattiset oireet (unettomuus, päänsärky, jännittyneisyys tai ahdistuneisuus, ylirasittuneisuus, yleinen väsymys tai heikkouden tunne, huimaus, painajaiset, käsien vapina, kuumotus tai hikoilu ilman ruumiillista työtä), tulot, työelämään sijoittuminen sekä taustamuuttujiksi sukupuoli, ikä, lapsettomuus ja tutkimukseen osallistumisvuosi. Psykosomaattisten oireiden osalta kysyttiin eri oireiden esiintymistiheyttä. Sukupuolikysymyksessä oli kaksi vastausvaihtoehtoa "mies" ja "nainen". Liitetaulukossa yksi on esitetty FINSEX-aineistosta käytetyt kysymykset, niiden vastausluokat ja luokille tehty uudelleenluokittelu.

Vastausluokkia yhdistettäessä on sisällöllisesti samantyyppisiä luokkia yhdistetty. Esimerkiksi tuloluokissa tulokymmenykset on tiivistetty tulokvintiileiksi. Aineiston alkuperäiskysymykset ja luokittelut näkyvät liitetaulukossa 1 .

Miesten ja naisten välisiä eroja onnellisuuden, sosioekonomisten muuttujien, psykosomaattisten oireiden ja elintapojen sekä intiimisuhteiden osalta analysoitiin ensin ristiintaulukoilla, joissa ti- 
lastollisia eroja tarkasteltiin Khiin neliö -testin (chi2 -testi) avulla.

Seuraavaksi, tarkastelimme onnellisuuteen yhteydessä olevia tekijöitä erikseen miesten ja naisten parissa binääristen logististen regressiomallien avulla. Regressiomallista raportoimme vetosuhteen (odds ratio, OR), joka kertoo kustakin selittävästä muuttujasta johtuvan suhteellisen todennäköisyyden sille, että vastaaja pitää elämäntilannettaan onnellisena. Binäärisessä logistisessa regressioanalyysissa ei saada täsmällistä mallin selitysastetta, mutta malleillemme on laskettu likiarvoiset selitysasteet (Pseudo $\mathrm{R}^{2}$ ).

Ensimmäisessä regressiotarkastelussa muuttujia tarkasteltiin yksi kerrallaan ja laskettiin muuttujakohtaiset vetosuhteet kullekin muuttujalle. Seuraavassa vaiheessa tämän tarkastelun pohjalta rakennettiin miehille ja naisille erilliset selitysmallit, jotka kontrolloivat myös muuttujien yhteisvaikutuksen. Malleihin otettiin mukaan ainoastaan yksittäisten muuttujien tarkastelussa merkitseviksi todettuja muuttujia. Aineistossa kaikki vastaajat eivät ole vastanneet kaikkiin kysymyksiin. Useita muuttujia sisältävissä malleissa otettiin mukaan tarkasteluun vastaamattomien luokka niiden muuttujien kohdalla, joissa yli 5 prosenttia oli jättänyt kysymykseen vastaamatta. Näin haluttiin estää aineiston suppeneminen regressiomallissa muiden muuttujien osalta.

\section{Parisuhteettomat miehet JA NAISET}

Tulokset paljastavat, että työikäisistä parisuhteettomista naisista suurempi osuus, 60 prosenttia, oli onnellisia, kun taas vastaavassa tilanteessa olevista miehistä onnellisia oli vain 40 prosenttia (Taulukko 1). Miehet kokivat myös naisia enemmän yksinäisyyttä. Miehistä viisi kuudesta koki jossain määrin yksinäisyyttä, naisista kaksi kolmesta. Naisista yli puolella asui kotonaan oma lapsi tai lapsia, miehistä vajaalla kolmanneksella. Ilman parisuhdetta oleville naisille uskonnolla oli suurempi merkitys kuin miehille. Naisista 44 prosenttia piti uskontoa tärkeänä tai erittäin tärkeänä, kun miehistä näin koki vain 26 prosenttia.

Parisuhteettomat miehet olivat seksuaalisesti aktiivisempia kuin ilman parisuhdetta olevat naiset. Naisista kaksi viidestä ilmoitti, että he eivät ole ollenkaan seksuaalisesti aktiivisia, miehillä vastaava osuus oli hieman alle kolmannes. Edellisestä yhdynnästä kulunut aika oli miehillä lyhyempi kuin naisilla. Naisissa oli yli kolmannes niitä, joilla edellisestä yhdynnästä oli kulunut jo yli kolme vuotta. Samaan aikaan parisuhteettomat naiset kuitenkin kokivat itsensä seksuaalisesti viehättävämmäksi kuin vastaavassa tilanteessa olevat miehet. Naisissa oli myös miehiin nähden kolminkertainen osuus vastaajia, jotka eivät olleet koskaan olleet tilanteessa, jossa olisivat kaivanneet sukupuolikumppania. Miehistä lähes puolet oli kaivannut kumppania ja kokenut, että kumppanin löytäminen oli vaikeaa. Naisista kumppanin löytämisessä vaikeuksia oli kokenut reilu kolmannes. Miehissä keskimäärin kuudenneksella ei ollut kokemuksia yhdynnästä, naisista kokemukset puuttuivat noin joka kymmenenneltä parisuhteettomalta vastaajalta. Ikä lisäsi yhdyntäkokemuksien todennäköisyyttä. 
Sekä naisista että miehistä yli puolet harrasti kunnon kohotukseen tai ylläpitoon tähtäävää liikuntaa vähintään kaksi kertaa viikossa. Miehistä noin viidennes ei harrastanut liikuntaa juuri lainkaan, naisissa liikuntaharrastus oli vähäistä vain joka kymmenennellä. Miehillä esiintyi naisia runsaampaa humalaan johtavaa alkoholinkäyttöä. Miehet olivat kuitenkin keskimäärin hieman naisia terveempiä. Miehissä oli enemmän niitä, joilla ei ollut lainkaan psykosomaattisia oireita ja naisilla oli enemmän oireiden kasautumista. Parisuhteettomat naiset kuuluivat parisuhteettomia miehiä korkeampiin tuloluokkiin. Tätä selittää naisten korkeampi koulutustaso sekä se, että parempituloisilla miehillä on muita miehï suurimpi todennäköisyys solmia parisuhde tai tulla valikoiduksi tällaiseen suhteeseen. Naisilla tulotasolla ei sen sijaan ole ollut yhteyttä siihen ovatko he solmineet parisuhteen. Miehistä työttömiä oli 17 prosenttia, naisista 11 . Vastaajissa eläkkeellä olevien osuus oli noin 18 prosenttia, sekä naisilla, että miehillä. Tämä on varsin korkea prosentti ottaen huomioon, että tarkasteltava ikäryhmä on alle 65 vuotiaita.

Taulukko 1. Onnellisuus, sosioekonominen asema, psykosomaattiset oireet, elintavat, sosiaaliset suhteet ja seksuaalisuus, työikäiset parisuhteettomat miehet $(n=519)$ ja naiset $(n=425)$, FINSEX-aineistossa

\begin{tabular}{|c|c|c|c|c|c|c|c|}
\hline & $\begin{array}{l}\text { Nainen } \\
n=519\end{array}$ & $\begin{array}{c}\text { Mies } \\
n=425\end{array}$ & $\begin{array}{c}\text { merkitsev } \\
\text { p-arvo }\end{array}$ & & $\begin{array}{l}\text { Nainen } \\
n=519\end{array}$ & $\begin{array}{c}\text { Mies } \\
n=425\end{array}$ & $\begin{array}{c}\text { merkitsev } \\
\text { p-arvo }\end{array}$ \\
\hline & $\%$ & $\%$ & & Sosiaaliset suhteet & $\%$ & $\%$ & \\
\hline Onnellisuus & & & $<0,001$ & |Yksinäisyys & & & $<0,001$ \\
\hline onnellinen & 61,2 & 39,2 & & yksinäinen & 22,5 & 35,8 & \\
\hline ei onnellinen & 38,8 & 60,8 & & vähän yksinäinen & 44,1 & 46,5 & \\
\hline Ikäryhmä vuosina & & & $<0,001$ & ei lainkaan yksinäinen & 33,4 & 17,7 & \\
\hline $25-34$ & 22,4 & 35,1 & & Olen sukupuolisesti puoleensavetävä & & & $<0,001$ \\
\hline $35-44$ & 20,0 & 21,6 & & samaa mieltä & 38,9 & 25,4 & \\
\hline $45-54$ & 24,1 & 24,1 & & ei samaa eikä erimieltä & 27,7 & 36,9 & \\
\hline $55-64$ & 33,5 & 21,9 & & erimieltä & 24,9 & 28,7 & \\
\hline Asuu lasten kanssa & & & $<0,001$ & ei vastausta & 8,5 & 8,9 & \\
\hline kyllä & 28,4 & 9,9 & & Oletteko koskaan ollut yhdynnässä & & & 0,002 \\
\hline Olen aikaisemmin ollut avo- tai avioliitossa & & & $<0,001$ & en ole & 8,0 & 14,5 & \\
\hline kyllä & 69,5 & 44,2 & & Sukupuolielämäni on kokonaisuudessaan ollut & & & 0,051 \\
\hline Tulokymmenys johon kuuluu & & & 0,034 & tyydyttävää & 37,2 & 37,2 & \\
\hline 1) $1-2$, alle $600 € /$ kk netto (vuonna 2015) & 18,7 & 23,1 & & en osaa sanoa & 34,7 & 27,5 & \\
\hline 2) $3 \& 4,601-1050 € /$ kk netto (vuonna 2015) & 22,4 & 26,4 & & epätyydyttävää & 24,1 & 31,1 & \\
\hline 3) $5 \& 6,1051-1450 € /$ kk netto (vuonna 2015) & 30,4 & 21,9 & & ei vastausta & 6,2 & 4,2 & \\
\hline 4) $7 \& 8,1451-1850 € / \mathrm{kk}$ netto ( vuonna 2015) & 14,6 & 15,6 & & Kumppanin löytäminen kaivattaessa & & & $<0,001$ \\
\hline 5) 9 \& 10 yli $1851 € /$ kk netto (vuonna 2015) & 11,8 & 13,0 & & vaikeaa & 29,7 & 38,6 & \\
\hline Työtilanne & & & 0,013 & ei helppoa eikä vaikeaa & 12,9 & 22,6 & \\
\hline töissä tai opiskelija & 69,1 & 63,4 & & helppoa & 16,8 & 12,2 & \\
\hline työtön tai lomautettu & 10,6 & 17,0 & & en ole kaivannut & 24,5 & 9,2 & \\
\hline eläkkeellä & 18,0 & 18,6 & & ei vastausta & 16,2 & 17,4 & \\
\hline muu & 2,3 & 0,9 & & \multicolumn{2}{|l|}{ Onko olemassa mies tai nainen joka todella rakastaa sinua } & & 0,583 \\
\hline Terveys ja elintavat & & & & kyllä & 17,3 & 19,2 & \\
\hline Viimeisen kuukauden aika esiintyneet psykosomaa & attiset oir & & & ei & 77,1 & 74,1 & \\
\hline summa muuttujan keskiarvo & 13,5 & 13,0 & & en tiedä (vaihtoehto vain 1992) & 5,6 & 6,7 & \\
\hline Liikunta & & & $<0,001$ & Kysymyksiin vastausvuosi & & & 0,455 \\
\hline ainakin kaksi kertaa viikossa & 65,5 & 54,4 & & 1992 & 24,1 & 26,1 & \\
\hline 2-4 kertaa kuukaudessa & 21,2 & 22,7 & & 1999 & 13,9 & 16,2 & \\
\hline muutaman kerran vuodessa & 13,2 & 22,9 & & 2007 & 32,9 & 28,7 & \\
\hline Katson uskonnon merkityksen elämässäni & & & $<0,001$ & 2015 & 29,1 & 28,9 & \\
\hline hyvin tärkeäsksi & 13,3 & 6,9 & & & & & \\
\hline tärkeäksi & 30,9 & 19,1 & & & & & \\
\hline ei tärkeäksi & 55,9 & 74,0 & & & & & \\
\hline Alkoholin käyttö humalaan asti & & & $<0,001$ & & & & \\
\hline vähintään pari kertaa viikossa & 0,2 & 6,6 & & & & & \\
\hline 1-4 krt kuukaudessa & 12,3 & 37,6 & & & & & \\
\hline harvemmin kuin kerran kuukaudessa & 38,3 & 34,4 & & & & & \\
\hline en lainkaan & 49,2 & 21,5 & & & & & \\
\hline
\end{tabular}




\section{ONNELLISUUDEN YHTEYS ERI OSATEKIJÖIHIN}

Sekä naisten että miesten onnellisuutta lisäsi muuttujakohtaisissa yhden muuttujan binäärisissä regressiomalleissa tunne siitä, ettei ole yksin ja hyvä psykosomaattinen terveys. Tilastollisesti merkitseviä selittäjiä olivat myös oma koettu tyytyväisyys omaan sukupuolielämään kokonaisuudessaan, uskonnollisuus, oma koettu viehättävyys, liikunnan harrastus ja työ- tai opiskeluelämään kiinnittyminen.

Näiden muuttujien lisäksi naisilla onnellisuus oli yhteydessä korkeisiin tuloihin. Miehillä onnellisuutta lisäsivät edellisten lisäksi helpoksi koettu kumppanin löytäminen, rakkaan ihmisen olemassaolo ja vähäinen alkoholin humalakäyttö. Parisuhdehistoriaa kuvaava muuttuja "oletko ollut avo- tai avioliitossa" ei osoittautunut parisuhteettomien onnellisuuden kannalta merkitseväksi selittäjäksi. Kotona asuvat lapset eivät vaikuttaneet onnellisuuteen merkitsevästi, kuten ei myöskään vastaajan ikäluokka tai kyselyyn osallistumisvuosi.

Yhdistelmämalliin tuotiin kaikki yhden muuttujan mallissa tilastollisesti merkitsevinä onnellisuutta selittäneet muuttujat. Malleista rakentui hieman erilaiset työikäisille miehille ja naisille. Yhdistelmämallissa naisilla merkitsevimmiksi onnellisuuden selittäjiksi nousivat vähäinen koettu yksinäisyys ja hyvä psykosomaattinen terveys. Myös uskonnollisuus ja tulot säilyivät yhteismallissa merkitsevinä onnellisuuden selittäjinä. Näin rakennetulla mallilla saatiin parisuhteettomien naisten onnellisuutta selitettyä noin 46 prosent- tia eli selitysasteeksi pseudo $\mathrm{R}^{2}$ saatiin 0,46 .

Tärkeimmiksi muuttujiksi miesten onnellisuutta selitettäessä osoittautui hyvä psykosomaattinen terveys, viikoittainen liikuntaharrastus ja vähäinen humalajuominen. Työ- tai opiskeluelämään kiinnittyminen ja tyytyväisyys omaan sukupuolielämään kokonaisuudessaan olivat myös keskeisiä onnellisuuden selittäjiä. Tämä yhdistelmämalli selitti miesten onnellisuutta noin 27 prosenttia eli miesten onnellisuuden selitysaste pseudo $\mathrm{R}^{2}$ oli 0,27 .

\section{Pohdinta}

Nyt tehty tutkimus osoittaa, että työikäiset parisuhteettomat naiset ovat miehï merkitsevästi onnellisempia (naiset 61\%, miehet 39\%). Koko väestöä tarkastelevassa World Values Surveyhin pohjaavassa tutkimuksessa on todettu naisten suurempi tai vähintään miesten tasoa oleva onnellisuus (Zweig 2015), samaan tulokseen on tultu myös Japanissa (Yoko ym. 2018). Koko väestöä kuvaavat erot eivät kuitenkaan ole yhtä suuria kuin nyt näyttäytyvä parisuhteettomien onnellisuusero. 96 maata kattavassa onnellisuustutkimuksessa Gallup World Poll) sukupuolten välisen onnellisuuden eron suunta vaihteli maittain. Naiset olivat miehiä onnellisempia 27 maassa ja miehet naisia onnellisempia 16 maassa keskimääräisen onnellisuuseron ollessa vain 0.18 yksikköä, kun onnellisuutta kysyttiin asteikolla 1-10. (Meisenberg \& Woodley 2015).

Parisuhteettomat miehet myös kokivat itseänsä parisuhteettomia naisia useam- 
Taulukko 2. Onnellisuuden yhteys sosioekonomiseen asemaan, psykosomaattisiin oireisiin, liikuntaan, uskonnollisuuteen, alkoholin käyttöön, yksinäisyyteen, intiimisuhteisiin ja kyselyn suorittamisajankohtaan; binäärinen logistinen regressiomalli, parisuhteettomat naiset ja miehet.

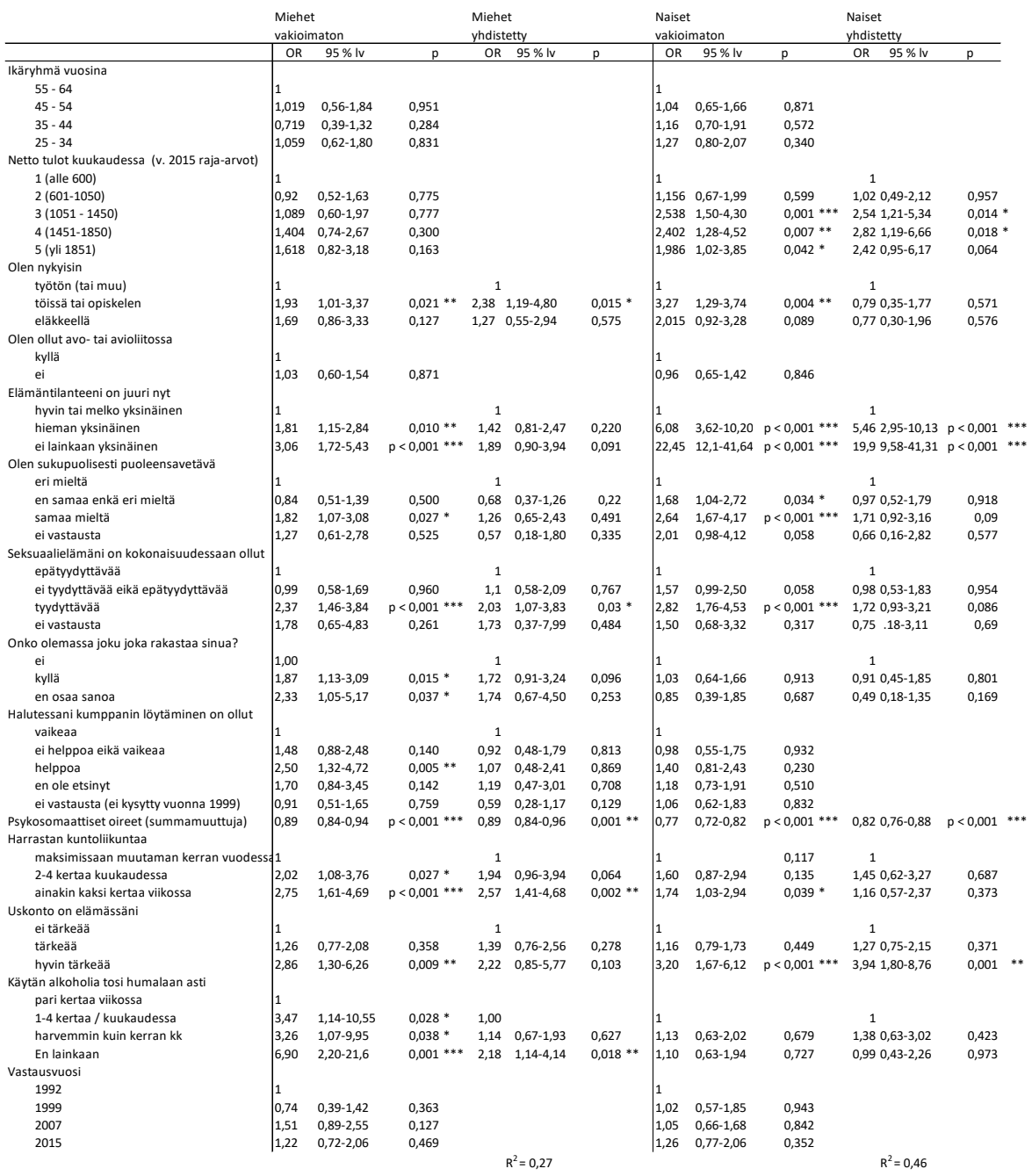


min yksinäiseksi. Miehistä vain 17,7 prosenttia ilmoitti, ettei koe itseään lainkaan yksinäiseksi. Aikaisemmissa suomalaisissa tutkimuksissa erityisesti keski-ikäiset miehet on tunnistettu yksinäisyyden kannalta haavoittuvaksi ryhmäksi (Kontula 2013; Kainulainen 2016). Tutkimuksen naiset myös kokivat miehï useammin itsensä sukupuolisesti puoleensavetäväksi ja kokivat kumppanin löytämisen harvemmin vaikeaksi.

Naiset olivat miehï liikunnallisempia ja uskonnollisempia. Suomessa myös väestötasolla vähintään kaksi kertaa viikossa ainakin puoli tuntia kerrallaan vapaa-ajan liikuntaa harrastavien osuus oli naisilla miehiä korkeampi (Turpeinen \& Hakamäki 2018). Voidaan kuitenkin todeta, että sekä parisuhteettomat naiset että miehet liikkuvat muuta ikäryhmäänsä enemmän.

Parisuhteettomien naisten onnellisuus on hyvin vahvasti yhteydessä vähäisiin yksinäisyyden kokemuksiin. Tuloksissa parisuhteettomien naisten onnellisuus näyttäytyykin ensisijaisesti vähäisen yksinäisyyden ja hyvän psykosomaattisen terveyden sanoittamalta. Naisista lähes kolmanneksella asui samassa taloudessa lapsia. Lapset eivät kuitenkaan tilastollisesti merkitsevästi vähentäneet yksinäisyyttä. Näyttääkin, että yksinäisyyttä lievittämään tarvitaan nimenomaan toinen aikuinen. Lasten onnellisuutta lisäävä vaikutus on todettu tilapäiseksi myös parisuhteessa elävillä (Myrskylä \& Margolis 2014) ja 90 tutkimusta käsittävässä review-artikkelin perusteella lasten hankinta laskee parisuhdetyytyväisyyttä (Twenge ym. 2003). Aikaisemmassa tutkimuksessa on todettu, että naimisissa olevat naiset ja miehet kääntyvät tuen ja avun tarpeessa ensisijaisesti puolisonsa puoleen (Gerstel \& Sarkisian 2006), parisuhteettomat tukeutuvat ystäviin, kollegoihin ja laajempaan perheeseen turvallisuuden ja kuuluvuuden tunteen saamiseksi. Sosiaalisten suhteiden verkoston ja sosiaalisiin aktiviteetteihin osallistumisen on todettu olevan yhteydessä onnellisuuteen. Kislevin (2019) tutkimuksessa tämän yhteyden todetaan olevan erityisen voimakas parisuhteettomilla, jotka onnistuvat naimisissa olevia paremmin hyödyntämään sosiaalista pääomaa onnellisuuden lähteenä.

Miksi tutkimuksessamme onnellisuus oli yhteydessä yksinäisyyteen juuri naisilla, mutta ei vakioidussa mallissa miehillä? Yksi selitys voisi olla, että sosiaalisia verkostoja on pidetty perinteisesti erityisesti naisten vahvuutena. Sosiaalisen verkoston puute näyttäytyy tällöin normista poikkeamana erityisesti naisten kohdalla. Yksinäisiksi itsensä kokevilla naisilla voi olla myös miehiä enemmän tarvetta sosiaalisen verkoston tarjoamaan tukeen käytännön asioissa.

Uskonnollisuus oli naisilla vähäisen yksinäisyyden ja vähäisten psykosomaattisten oireiden jälkeen merkitsevin onnellisuuden selittäjä. Uskonnon vaikutusta onnellisuuteen on perusteltu osittain uskonnollisten yhteisöjen tuomalla sosiaalisella verkostolla. Uskonnollisuus säilyi naisilla mukana myös yhteismallin selittävissä muuttujissa, joten uskonto tarjoaa myös jotain muuta kuin vain lievitystä yksinäisyyteen. Vaikutusmekanismi ei kuitenkaan selviä nyt tehdystä tutkimuksesta. Aikaisemmissa tutkimuksissa uskonnollisuuden on todettu olevan yhteydessä parempaan stressin hallintaan ja 
vähentävän masennuksen, itsemurhan, ahdistuksen ja päihteiden väärinkäytön todennäköisyyttä (Koenig 2009; Ano ym. 2005). Uskonnollisuuden on myös todettu olevan yhteydessä positiiviseen maailmankuvaan ja tarjoavan elämälle merkitystä myös vaikeina aikoina (Koenig 2009).

Naisten kohdalla tulotaso oli yhteydessä onnellisuuteen, mutta työtilanne ei. Miesten kohdalla puolestaan työssä tai opiskelemassa olo lisäsi onnellisuutta, mutta tulotaso ei ollut yhteydessä onnellisuuteen. Työttömyyden negatiivinen vaikutus erityisesti miesten hyvinvointiin on todettu myös aikaisemmassa tutkimuksessa (Clark ym. 2008). Mahdollista on myös, että hyvä työmarkkina-asema tukee pysyvän parisuhteen löytymistä. Ainakin naimisiinmenohalukkuus näyttäisi olevan yhteydessä kumppanin hyviin tuloihin (Wiik ym. 2010).

Raha antaa mahdollisuuden tehdä valintoja muista riippumattomana ja toteuttaa näin mahdollisesti omia toiveita. Tavaroiden ostamisen onnellisuusvaikutus tiedetään varsin lyhytaikaiseksi, mutta tapahtumana kuluttamisen käytäntöihin liittyy myös sosiaalisia piirteitä, jotka voivat luoda kestävämpiä onnellisuuden tunteita (Goldsmith \& Flynn 2016). Yhteiset ostosreissut ystävien kanssa, matkailu ja kahvilakulttuurissa eläminen vaativat tuloja. Tutkimuksen naiset kuuluivat miehïä korkeampiin tuloluokkiin. Naisilla oli miehiä useammin lapsia samassa taloudessa, mikä voi osaltaan lisätä naisten elinkustannuksia. Voi olla mahdollista, että miehillä työ- tai opiskelupaikan sosiaaliset suhteet antavat merkityksellistä kuuluvuuden tunnetta, kun taas naisilla tämä kuuluvuus rakentuu ensisijaisesti ystäväverkostoissa ja onnellisuutta selittää työelämään integroitumista kuvaavaa muuttujaa paremmin näitä verkostoja kuvaava yksinäisyysmuuttuja.

Sekä miehillä että naisilla psykosomaattiset oireet ovat vahvasti yhteydessä onnellisuuteen. Onnellisuuden ja terveyden välinen yhteys on odotettu löydös aiemman tutkimuksen perusteella (Richards ym. 2015; Bjørnskov 2008; Mathew \& Paulose 2011; Dockray \& Steptoe 2010; Boehm \& Kubzansky 2012; Pressman \& Cohen 2005), eivätkä parisuhteettomat tehneet tästä poikkeusta. Parisuhteettomat naiset saivat hieman miehiä korkeamman pisteluvun psykosomaattisten oireiden summamuuttujalla, mutta olivat kuitenkin miehiin verrattuna selkeästi onnellisempia. Tähän vaikuttanee varmasti ainakin kaksi eri tekijää. Ensinnäkin naisten pisteluku rakentui useista lieväoireisista vastaajista ja pienestä joukosta vakavasti monioireisia. Miesten keskuudessa oli naisia tyypillisempää, että oirehtivalla oireet toistuivat usein, mikä on omiaan alentamaan onnellisuuden tunnetta. Toiseksi naisten onnellisuutta määrittivät keskeisesti myös muut tekijät kuten vähäinen yksinäisyys.

Onnellisille miehille on tyypillistä, että he harrastivat kuntoliikuntaa vähintään kaksi kertaa viikossa. Aikaisemmissa tutkimuksissa on todettu liikunnan yhteys onnellisuuteen (Ruseski ym. 2014; Huang \& Humphreys 2012; Balish ym. 2016) ja yhteyden olevan erityisen voimakas sosiaalisia suhteita tukevilla lajeilla (Downward \& Rasciute 2011). Liikuntaharrastusta muihin harrastuksiin vertaavassa yhteensä 48 maata kattavassa tutkimuksessa todetaan urheiluseuraan kuulumisen ennustavan 
onnellisuutta muuta seuratoimintaa paremmin (Balish ym. 2016). Liikunnan yhteyttä hyvinvointiin on selitetty ihmisen psykologisilla tarpeilla, kuten joukkoon kuuluminen, palautuminen työstressistä, autonomia ja tavoitteiden saavuttaminen (Kim \& James 2019). Tässä tutkimuksessa ei kuitenkaan ollut mahdollista selvittää eri liikuntamuotojen yhteyttä onnellisuuteen.

Nyt tehty tutkimus vahvisti seksuaalisen tyytyväisyyden tärkeyden myös parisuhteettomien miesten onnellisuuden rakentajana. Vaikka miehet näyttäytyivät tutkimuksessa keskimäärin seksuaalisesti naisia aktiivisempina, oli heidän joukossaan kuitenkin naisiin verrattuna enemmän niitä, joilta yhdyntäkokemukset puuttuivat täysin. Näyttää siis siltä, että parisuhteettomien miesten joukko jakautuu tässä naisia selkeämmin seksuaalisesti aktiivisiin ja passiivisiin. Siinä missä väestöotoksissa hyvinvoinnin kärjessä on perhe, parisuhteettomilla ei läheisiä ihmissuhteita kuvaava "on olemassa joku, joka rakastaa minua" noussut keskeiseksi selittäjäksi. Sosiaalisten verkostojen tyydyttävyyttä kuvasivat paremmin vähäinen yksinäisyys ja tyytyväisyys sukupuolielämään.

Yhteenvetona voidaan todeta, että työikäiset parisuhteettomat naiset ovat usein vastaavassa tilanteessa olevia miehï onnellisempia, liikunnallisempia ja uskonnollisempia. Naisilla oli myös usein miehiä parempi sosioekonominen asema. Hyvän sosioekonomisen aseman on todettu miehillä olevan yhteydessä parisuhteeseen valikoitumiseen, naisilla vastaavaa yhteyttä ei ole havaittu (Kontula 2008). Tyytymättömyys omaan sukupuolielämään kokonaisuudessaan, psykosomaattinen oireilu ja humalaan asti juominen yhdistettynä liikunnalliseen passiivisuuteen ja työelämän ulkopuolisuuteen kuvaavat parisuhteetonta miestä onnettomimmillaan. Työelämän ulkopuolisuus voi vaikuttaa itsetuntoon negatiivisesti, tyytymättömyys omaan seksuaalielämään kertoa pettymyksistä, ja näitä miehet pahimmassa tapauksessa lievittävät alkoholin voimalla.

Tutkimuksen muuttujat (intiimisuhteet, yksinäisyyden kokemus, liikunnallisuus, alkoholin käyttö, uskonnollisuus, psykosomaattiset oireet ja sosioekonominen asema) selittivät naisten onnellisuutta paremmin kuin miesten onnellisuutta. Tämä johtuu osittain siitä, että vaikka naiset kokivat miehï harvemmin yksinäisyyttä, heikensi se esiintyessään onnellisuutta erittäin voimakkaasti nimenomaan naisten kohdalla. Miesten kohdalla yksinäisyys ei laskenut onnellisuutta yhtä voimakkaasti, vaikkakin miehet kokivat naisia useammin yksinäisyyttä. Onnellisuus ja yksinäisyys eivät siis ole aivan suoraviivainen dikotomia, vaikka yhteys onkin hyvin selvä. Näyttää siltä, että naiset pystyvät paremmin hyödyntämään sosiaaliset suhteensa onnellisuuden lähteenä, mutta mikäli näitä suhteita ei ole, laskee onnellisuus erittäin voimakkaasti. $\mathrm{Pa}-$ risuhteettomien naisten onnellisuutta voisi lisätä tukemalla heitä sosiaalisten suhteiden muodostamisessa, kun taas miesten kohdalla tuen tulisi kohdistua liikunnallisuuteen kannustamiseen ja alkoholin käytön vähentämiseen. Molemmat sukupuolet hyötyisivät myös psykosomaattiseen terveyteen tähtäävien palveluiden helposta saatavuudesta.

Kuten kaikilla tutkimuksilla, tälläkin on rajoitteita. Yksilön onnellisuutta voidaan tulkita laajemmilla tai suppeammilla mittareilla. Laajempien kri- 
teeristöjen mukaan ihminen voi olla onnellinen vain, jos annetut kriteeristöt esimerkiksi ympäristön ja elämän hyödyllisyyden osalta täyttyvät (Pavot \& Diener 1993; Diener ym. 2009; Veenhoven 2013). FINSEX-tutkimuksessa on päädytty käyttämään suppeaa onnellisuuden määritelmää, jossa ihmisen onnellisuutta mitataan kysymällä vastaajan omaa arviota onnellisuudestaan. Lisäksi käyttämäämme FINSEXaineistoa rajoittaa käytettävissä olevien muuttujien määrä. Esimerkiksi parisuhteen ulkopuoliset ystävyyssuhteet ja perhesuhteet ovat todennäköisesti yhteydessä parisuhteettomien onnellisuuteen merkittävästi, mutta niitä ei voitu selvittää, sillä suhdeverkostoa kuvaavia muuttujia ei ollut tässä aineistossa käytettävissä. Yksinäisyyden kokemuksen voidaan kuitenkin katsoa kuvaavan sosiaalisten suhteiden verkostoa laadullisesti hyvin. Yksinäisyyden kokemuksessa on lopulta kysymys siitä, että nykyinen elämä ei vastaa niitä odotuksia, joita sosiaaliselle elämälle annetaan.

Onnellisuus on yksilön sisäinen tila ja ihminen voi myös erehtyä omasta tunnetilastaan (Haybron 2008). Tunnetilat ovat suhteessa aikaisemmin koettuun ja rajallinen kokemusmaailma tekee myös tunteiden tulkinnasta rajallista. Tutkija on tässä tilanteessa aina tutkittavien lausuntojen ja arvioiden varassa. Onnellisuus rakentuu myös olettamista. Ihmiset kiinnittävät onnellisuutta erilaisiin asioihin ja tilanteisiin yleisten onnellisuusolettamien pohjalta (Ahmed 2010). Esimerkiksi kuvitelma parisuhteen onnellisuutta lisäävästä vaikutuksesta voi saada henkilön kaipaamaan suhdetta, vaikka hänellä ei olisi mitään kokemusta parisuhteen vaikutuksesta onnellisuuteen.
Tietyissä väestöryhmissä, kuten esimerkiksi vankien ja alkoholistien parissa, voidaan olettaa ilman parisuhdetta elävien osuuden olevan korkeampi kuin muussa väestössä. Parisuhteettomia tarkasteltaessa on siksi tärkeää muistaa, että kokonaisväestöön perustuvilla kyselytutkimuksilla ei yleensä tavoiteta kaikkein huono-osaisimpia (Saari 2015). Yli 65-vuotiaissa naisissa parisuhteettomien osuus korostuu, tässä tutkimuksessa tarkasteltiin vain työikäisiä,joten tulokset eivät ole yleistettävissä kaikkiin parisuhteettomiin.

Parisuhteettomien onnellisuutta tutkittaessa tulisi jatkossa tarkastella parisuhteettomia erilaisissa elämäntilanteissa. Hyviä jatkotutkimuskohteita olisivat esimerkiksi maaseutujen ja kaupunkilaisten väliset erot ja parisuhteettomuus eri sosioekonomisissa luokissa. Parisuhteettomista ei voida puhua onnellisuuden suhteen yhtenäisenä joukkona, vaan tarkempaa tutkimusta tarvitaan.

Tutkimusta on rahoittanut Kulttuurirahaston Etelä-Savon maakuntarahasto.

\section{KiRJallisuUs}

Ahmed, Sara (2010) The promise of Happiness. London: Duke University Press. https://doi.org/10.2307/j.ctv125jkj2

Ano, Gene \& Vasconcelles, Erin (2005) Religious Coping and Psychological Adjustment to Stress: A Meta-Analysis. Journal of Clinical Psychology 61 (4), 461-480. https://doi.org/10.1002/jclp.20049

Balish, Shea M \& Conacher, Dan \& Dithurbide, Lori (2016) Sport and Recreation Are Associated With Happiness Across Countries. Research Quarterly for Exercise and Sport 87 (4), 382-388. https://doi.org/10 $.1080 / 02701367.2016 .1229863$

Baumeister, Roy F \& Leary, Mark R (1995) The Need to Belong:Desire for Interpersonal Attachments as a Fundamental Human 
Motivation. Psychological Bulletin 117 (3), 497-529. https://doi.org/10.1037/00332909.117.3.497

Berlin, Martin \& Kaunitz, Niklas (2015) Beyond Income: The Importance for Life Satisfaction of Having Access to a Cash Margin. Journal of Happiness Studies 16 (6), 1557-1573. https://doi.org/10.1007/ s10902-014-9575-7

Beutel, Manfred E. \& Stöbel-Richter,Yve \& Brähler, Elmar (2008) Sexual desire and sexual activity of men and women across their lifespans: results from a representative German community survey. BJU International, 101 (1), 76-82. https://doi. org/10.1111/j.1464-410X.2007.07204.x

Bjørnskov, Christian (2008) Healthy and happy in Europe? On the association between happiness and life expectancy over time. Social Science \& Medicine 66 (8), 1750-1759. https://doi.org/10.1016/j. socscimed.2008.01.031

Blanchflower, David G. \& Oswald, Andrew J. (2004) Money, Sex and Happiness: An Empirical Study. Scandinavian Journal of Economics 106 (3), 393-415. https://doi. org/10.1111/j.0347-0520.2004.00369.x

Boehm, J. K., \& Kubzansky, L. D. (2012). The heart's content: The association between positive psychological well-being and cardiovascular health. Psychological Bulletin 138 (4), 655-691. https://doi. org/10.1037/a0027448

Budgeon, Shelley (2008) Couple Culture and the Production of Singleness. Sexualities 11 (3), 301-325. https://doi. org/10.1177/1363460708089422

Cacioppo, John T. \& Hughes, Mary Elisabeth \& Waite, Linda J. \& Hawkley, Luise C. \& Thisted, Ronald A (2006) Loneliness as a Specific Risk Factor for Depressive Symptoms: Cross-Sectional and Longitudinal Analyses. Psychology and Ageing 21 (1), 140-151. https://doi.org/10.1037/08827974.21.1.140

Clark, Andrew E. \& Diener, Ed \& Georgellis, Yannis \& Lucas, Richard E. (2008) Lags and Leads in Life Satisfaction: A Test of the Baseline Hypothesis. The Economic Journal 118 (529), 222-243. https://doi. org/10.1111/j.1468-0297.2008.02150.x

DePaulo, Bella (2014) A Singles Studies Perspective on Mount Marriage. Psychological Inquiry 25 (1), 64-68. https://doi.
org/10.1080/1047840X.2014.878173

Diener, Edward \& Wirtz, Derrick \& Tov, William \& Kim-Prieto, Chu \& Choi, D. \& Oishi, Shiege \& Biswas-Diener, Robert (2009) New Measures of well-being. Social Indicators Research 39, 247-266. https:// doi.org/10.1007/978-90-481-2354-4_12

Diener, Edward \& Seligman, Martin E.P (2002) Very happy people. Psychological Science 13 (1), 80-83. https://doi. org/10.1111/1467-9280.00415

Diener, Edward \& Oishi, Shigehiro (2005) The Nonobvious Social Psychology of Happiness. Psychological Inquiry 16 (4), 162-167. https://doi.org/10.1207/ s15327965pli1604_04

Dockray, Samantha \& Steptoe, Andrew (2010) Positive affect and psychobiological processes. Neuroscience and Biobehavioral Reviews 35 (1), 69-75. https://doi. $\mathrm{org} / 10.1016 / \mathrm{j}$. neubiorev.2010.01.006

Downward, Paul \& Rasciute, Simona (2011) Does sport make you happy? An analysis of the well-being derived from sports participation. International Review of Applied Economics 25 (3), 331-348. https://doi.or $\mathrm{g} / 10.1080 / 02692171.2010 .511168$

Eurostat (2019) Distribution of population by household types. https://ec.europa.eu/ eurostat $/ \mathrm{tgm} / \mathrm{table}$.do?tab=table\&init $=1$ \&language $=$ en $\&$ pcode $=$ tesov $190 \& p l u g$ in=1. Luettu 22.5.2019.

Gerstel, Naomi R \& Sarkisian, Natalia (2006) Marriage: The Good, the Bad, and the Greedy. Contexts 5 (4), 16-21. https://doi. org/10.1525/ctx.2006.5.4.16

Goldsmith, Ronald \& Flynn, Fleisa Reinecke (2016) The big five, happiness, and shopping. Journal of Retailing and Consumer Services 31, 52-61. https://doi. org/10.1016/j.jretconser.2016.03.007

Haavio-Mannila, Elina \& Kontula, Osmo \& Kuusi, Elina (2001) Trends in Sexual Life: Measured by national sex surveys in Finland in 1971, 1992 and 1999 and a comparison to a sex survey in St.Petersburg in 1996. Working Papers E 10/2001. The Population Research Institute. Helsinki: The Family Federation of Finland.

Haybron, Daniel M. (2008) The Pursuit of Unhappiness: The Elusive Psychology of Well-being. Oxford: Oxford University Press.

Helliwell, John F. \& Layard, Richard \& Sachs, 
Jeffrey \& De Neve, Jan-Emmanuel (2020) World Happiness Report 2020. New York: Sustainable Development Solutions Network.

Hostetler, Andrew J. (2012) Singlehood and Subjective Well-Being among Mature Gay Men: The Impact of Family, Friends, and of Being "Single by Choice". Journal of GLBT Family Studies 8 (4), 361384. https://doi.org/10.1080/155042 8X.2012.705621

Huang, Haifang \& Humphreys, Brad R (2012) Sports participation and happiness: Evidence from US microdata. Journal of Economic Psychology 33 (4), 776-793. https://doi.org/10.1016/j. joep.2012.02.007

Junttila, Niina (2015) Kavereita nolla: Lasten ja nuorten yksinäisyys. Helsinki:Tammi.

Junttila, Niina \& Kainulainen, Sakari \& Saari, Juho (2015) Mapping the lonely landscape: Assessing loneliness and its consequences. The Open Psychology Journal 8 (1), 89-96. https://doi. org/10.2174/1874350101508010089

Kageyama, Junji (2012) Happiness and Sex Difference in Life Expectancy. Journal of Happiness Studies 13 (5), 947-967.https:// doi.org/10.1007/s10902-011-9301-7

Kahneman, Daniel \& Krueger, Alan B \& Schkade, David \& Schwarz, Norbert \& Stone, Arthur (2004) Toward National Well-Being Accounts. American Economic Review 94 (2), 429-434. https://doi. org/10.1257/0002828041301713

Kainulainen, Sakari (2014) Raha ja rakkaus hyvinvoinnin lähteinä.Yhteiskuntapolitiikka 79 (5), 485-497.

Kainulainen, Sakari (2016) Yksinäisen elämänlaatu. Teoksessa Juho Saari (toim.) Yksinäisten Suomi. Helsinki: Gaudeamus, 114-125.

Kangas, Olli (2010) One hundred years of money, welfare and death: mortality, economic growth and the development of the welfare state in 17 OECD countries 19002000. International Journal of Social Welfare 19, 42-59. https://doi.org/10.1111/ j.1468-2397.2010.00735.x

Kim, Jeeyon \& James, Jeffrey D. (2019) Sport and Happiness: Understanding the Relations Among Sport Consumption Activities, Long- and Short-Term Subjective Well-Being, and Psychological Need Ful- fillment. Journal of Sport Management 33 (2), 119-132. https://doi.org/10.1123/ jsm.2018-0071

Kinnunen, Anu \& Kontula, Osmo (2018) Miesten parisuhteettomuuden yhteys hyvinvointiin. Sosiaalilääketieteellinen $\mathrm{Ai}$ kakauslehti 55 (1), 22-34. https://doi. org/10.23990/sa.69222

Kislev, Elyakim (2020) Social Capital, Happiness, and the Unmarried: a Multilevel Analysis of 32 European Countries. Applied Research in Quality of Life. 15, 14751492. https://doi.org/10.1007/s11482019-09751-y

Knowles, Megan L. (2014) Social rejection increases perspective taking. Journal of Experimental Social Psychology 55, 126-132. https://doi.org/10.1016/j. jesp.2014.06.008

Koenig, Harold D (2009) Research on Religion, Spirituality, and Mental Health: A Review. The Canadian Journal of Psychiatry 54 (5), 283-291. https://doi. org/10.1177/070674370905400502

Koivumaa-Honkanen, H \& Kaprio, J \& Korhonen, T \& Honkanen, R J \& Heikkilä, K \& Koskenvuo, M (2012) Self-reported life satisfaction and alcohol use: a 15-year follow-up of healthy adult twins. Alcohol and alcoholism 47 (2), 160-168. https:// doi.org/10.1093/alcalc/agr151

Kontula, Osmo (2008) Halu ja intohimo: Tietoa suomalaisesta seksistä. Helsinki: Otava.

Kontula, Osmo (2011) Hyvinvoinnin ja onnen tärkeät rakennusaineet: Parisuhde ja seksuaalinen intimiteetti. Teoksessa Osmo Kontula (toim.) Suomalaisen hyvinvoinnin ja onnellisuuden tulevaisuus. Helsinki:VLMarkkinointi, 262-273.

Kontula, Osmo (2013) Yhdessä vai erikseen?: tutkimus suomalaisten parisuhteiden vahvuuksista, ristiriidoista ja erojen syistä. Helsinki:Väestöliitto.

Kontula, Osmo (2016) Lemmen paula: Seksuaalinen hyvinvointi parisuhdeonnen avaimena. Perheparometri 2016. Väestöntutkimuslaitos. Katsauksia E50/2016. Helsinki:Väestöliitto.

Kontula, Osmo \& Saari, Juho (2016). Yksinäisyys parisuhteessa. Teoksessa Juho Saari (toim.) Yksinäisten Suomi. Helsinki: Gaudeamus.

Lahad, Kinneret (2017) A table for one: A 
critical reading of singlehood, gender and time. Manchester: Manchester University Press.

Lewis, Karen Gail \& Moon, Sidney (1997) Always single and single again women: a qualitative study. Journal of Marital and $\mathrm{Fa}-$ mily Therapy 23 (2), 115-34. https://doi. org/10.1111/j.1752-0606.1997.tb00238.x

Lun,Vivien \& Bond, Michael (2016) Achieving Subjective Well-Being Around the World:The Moderating Influence of Gender,Age and National Goals for Socializing Children. Journal of Happiness Studies 17 (2), 587-608. https://doi.org/10.1007/ s10902-015-9614-z

Maksimainen, Jaana (2014) Avioliiton pelastamisesta parisuhteen hoitamiseen. Sosiologia 51 (2), 123-138.

Mathew, Jobin \& Paulose, Cheramadathikudyl S. (2011) The healing power of wellbeing. Acta Neuropsychiatrica 23 (4), 145-155. https://doi.org/10.1111/j.16015215.2011.00578.x

Meisenberg, Gerhard \& Woodley, Michael A. (2015) Gender Differences in Subjective Well-Being and Their Relationships with Gender Equality. Journal of Happiness Studies 16 (6) 1539-1555. https://doi. org/10.1007/s10902-014-9577-5

Musick, Kelly \& Bumpass, Larry (2012) Reexamining the Case for Marriage: Union Formation and Changes in Wellbeing. Journal of marriage and family 74 (1), 1-18. https://doi.org/10.1111/j.17413737.2011.00873.x

Myrskylä, Mikko \& Margolis, Rachel (2014) Happiness: Before and After the Kids Demography 51 (5), 1843-1866. https://doi. org/10.1007/s13524-014-0321-x

Müller, Kiti \& Lehtonen, Johannes (2016) Yksinäisyys, aivot ja mieli. Teoksessa Juho Saari (toim.) Yksinäisten Suomi. Helsinki: Gaudeamus, 73-95.

Ngamaba, Kayonda Hubert \& Panagioti, Maria \& Armitage, Christopher J. (2017) How strongly related are health status and subjective well-being? Systematic review and meta-analysis. European Journal of Public Health 27 (5), 879-885. https://doi. org/10.1093/eurpub/ckx081

Pavot, William \& Diener, Ed (1993) Review of the satisfaction with life scale. Psychological Assessment 5 (2), 164-172. https:// doi.org/10.1037/1040-3590.5.2.164
Pessi, Anne Birgitta (2008) What constitutes Experiences of Happiness and Good Life: Building a Novel Model on the Everyday Experiences. Teoksessa Heli Tissari, Anne Birgitta Pessi \& Mikko Salmela (toim.) Happiness: Cognition, Experience, Language. Helsinki: Helsinki Collegium for Advanced Studies.

Reynolds, Jill \& Wetherell, Margaret \&Taylor, Stephanie (2007) Choice and chance: negotiating agency in narratives of singleness. Sociological Review 55 (2), 331351. https://doi.org/10.1111/j.1467954X.2007.00708.x

Pressman, Sarah D. \& Cohen, Sheldon (2005) Does positive affect influence health? Psychological Bulletin, 131 (6), 925-971. https://doi.org/10.1037/00332909.131.6.925

Richards, Justin \& Jiang, XiaoXiao \& Kelly, Paul \& Chau, Josephine \& Bauman, Adrian \& Ding, Ding (2015). Don't worry, be happy: cross sectional associations between physical activity and happiness in 15 European countries. BMC public health 15 (1), 53-53. https://doi.org/10.1186/s12889015-1391-4

Richmond, Peter \& Roehner, Bertrand M. (2017) Impact of marital status on health. Physica A: Statistical Mechanics and its Applications 486, 542-553. https://doi. org/10.1016/j.physa.2017.05.079

Ruseski, Jane E. \& Humphreys, Brad R. \& Hallman, Kirstin \& Wicker, Pamela \& Breuer, Christoph (2014) Sport participation and subjective well-being: instrumental variable results from German survey data. Journal of Physical Activity \& Health 11 (2), 396-403. https://doi.org/10.1123/ jpah.2012-0001

Saari, Juho (2012) Onnellisuuspolitiikka. Kohti sosiaalisesti kestävää Suomea. Jyväskylä: Kalevi Sorsa -säätiö.

Saari, Juho (2015) Huono-osaiset: elämän edellytykset yhteiskunnan pohjalla. Helsinki: Gaudeamus.

Saarinen, Arttu \& Airio, Ilpo \& Kaikkonen, Risto \& Luoma, Minna-Liisa (2013) Onnellisuus erityyppisillä asuinalueilla. Yhteiskuntapolitiikka 78 (5), 520-532.

Sievers, Kai \& Kortelainen, Osmo \& Leppo, Kimmo (1974) Suomalaisten sukupuolielämä. Porvoo:Werner Söderström.

Simpson, Roona (2016) Singleness and self- 
identity: The significance of partnership status in the narratives of never-married women. Journal of Social and Personal Relationships 33 (3), 385-400. https://doi. org/10.1177/0265407515611884

Sini,Toikka \&Vuorjoki, Ona \& Koskela,Tuomas \& Pentala, Oona (2015) Aikuisväestön yksinäisyys ja järjestötoimintaan osallistuminen Suomessa - ATH-tutkimuksen tuloksia. Teoksessa Jukka Murto, Oona Pentala, Satu Helakorpi \& Risto Kaikkonen (toim.) Yksinäisyys ja osallistuminen, ATH-tutkimuksen tuloksia: Järjestökentän tutkimusohjelma. Helsinki: Terveyden ja hyvinvoinnin laitos, 9-14.

Solé-Auró, Aïda \& Jasilionis, Domantas \& Li, Peng \& Oksuzyan, Anna (2018) Do women in Europe live longer and happier lives than men? European Journal of Public Health 28 (5), 847-852. https://doi. org/10.1093/eurpub/cky070

Suomen virallinen tilasto (SVT) (2020) Asunnot ja asuinolot, Liitetaulukko 1. Asuntokunnat koon mukaan ja asuntokuntien keskikoko 1960-2019. Helsinki: Tilastokeskus.

Suomen virallinen tilasto (SVT) (2019) Siviilisäädyn muutokset 2018. Helsinki: Tilastokeskus.

Sun, Sun \& Chen, Jiaying \& Johannesson, Magnus \& Kind, Paul \& Burström, Kristina (2016) Subjective Well-Being and Its Association with Subjective Health Status, Age, Sex, Region, and Socio-economic Characteristics in a Chinese Population Study. Journal of Happiness Studies 17 (2), 833-873. https://doi.org/10.1007/ s10902-014-9611-7

Stack, Steven \& Eshleman, J. Ross (1998) Marital status and happiness: A 17-nation study. Journal of Marriage and the Family 60 (2), 527-536. https://doi. org/10.2307/353867

Stavrova, Olga \& Fetchenhauer, Deflev \& Schlösser, Thomas (2012) Cohabitation, Gender, and Happiness: A Cross-Cultural Study in Thirty Countries. Journal of Cross-Cultural Psychology 43 (7), 1063-1081. https://doi. org/10.1177/0022022111419030

Terämä, Emma \& Tiitu, Maija \& Paavola, Juho-Matti \& Vainio, Arttu \& Määttänen, Niku \& Miettinen, Anneli \& Kontula, Osmo \& Hiilamo, Heikki (2018) Yksin osana elinkaarta (Alone along the life cycle). Valtioneuvoston selvitys- ja tutkimustoiminnan julkaisusarja 66/2018.

Turpeinen, Salla \& Hakamäki, Matti (2018) Liikunta ja tasa-arvo 2017 Katsaus sukupuolten tasa-arvon nykytilaan liikuntaalalla. Opetus- ja kulttuuriministeriön julkaisuja 6. Helsinki: Opetus- ja kulttuuriministeriö.

Twenge, Jean M \& Campbell, W. Keith \& Foster, Craig A (2003) Parenthood and Marital Satisfaction: A Meta-Analytic Review. Journal of Marriage and Family 65 (3), 574-583. https://doi.org/10.1111/ j.1741-3737.2003.00574.x

Van Cappellen, Patty \& Toth-Gauthier, Maria \& Saroglou, Vassilis \& Fredrickson, Barbara (2016) Religion and Well-Being:The Mediating Role of Positive Emotions. Journal of Happiness Studies 17 (2), 485-505. https://doi.org/10.1007/s10902-0149605-5

Veenhoven, Ruut (2013) Notions of the Good Life. Teoksessa Susan A David, Ilona Boniwell \& Amanda Conley Ayers (toim.) The Oxfors Handbook of Happiness. Oxford: Oxford University Press, 161-173. https://doi.org/10.1093/oxfordhb/9780199557257.013.0012

Wiik, Kenneth Aarskaug \& Bernhardt, Eva \& Noack, Turid (2010) Love or Money?: Marriage Intentions among Young Cohabitors in Norway and Sweden. Acta Sociologica 53 (3), 269-287. https://doi. org/10.1177/0001699310374488

Yoko, Moriyama \& Nanako, Tamiya \& Kawachi, Nobuyuki \& Maya, Miyairi (2018) What Makes Super-Aged Nations Happier? Exploring Critical Factors of Happiness Among Middle-Aged Men and Women in Japan. World Medical \& Health Policy 10 (1), 83-98. https://doi.org/10.1002/ wmh3.256

Zweig,Jacqueline S. (2015) Are Women Happier than Men? Evidence from the Gallup World Poll. Journal of Happiness Studies 16 (2), 515-541. https://doi.org/10.1007/ s10902-014-9521-8 
Liitetaulukko 1. Kysymykset aineistossa, vastausluokat ja uudelleenluokittelu

\begin{tabular}{|c|c|c|}
\hline \multicolumn{3}{|l|}{ Taustamuuttujat } \\
\hline Minä vuonna olette syntynyt? & syntymävuosi & ikä vuosina \\
\hline $\begin{array}{l}\text { Oletko tällä hetkellä? } \\
\text { Asutteko tällä hetkellä avoliitossa? }\end{array}$ & $\begin{array}{l}1=\text { naimaton, } 2=\text { naimisissa asuen yhdessä } \\
\text { puolison kanssa, } 3=\text { naimisissa asuen } \\
\text { erillään, } 4=\text { eronnut, } 5=\text { leski. } \\
\text { kyllä/ei }\end{array}$ & $\begin{array}{l}1=\text { ei naimisissa }(1,4 \& 5) \\
2=\text { naimisissa }(2 \& 3)\end{array}$ \\
\hline $\begin{array}{l}\text { Onko Teillä muu parisuhde, mutta ette asu kuitenkaan yhdessä? } \\
\text { Oletteko solminut avo- tai avioliton? }\end{array}$ & $\begin{array}{l}1=\text { ei ole, } 2=\text { kyllä, yksi, } 3=\text { on, kaksi tai } \\
\text { useampia. } \\
\text { Kyllä/ei }\end{array}$ & kyllä/ei \\
\hline Onnellisuus & Kyllä/ei & \\
\hline $\begin{array}{l}\text { Millaisena pidätte elämäänne juuri nyt? } \\
\text { Sosiaaliset suhteet }\end{array}$ & $1=$ hyvin onnellista, $5=$ hyvin onnetonta & $\begin{array}{l}1=\text { onnellinen }(1 \& 2) \\
2=\text { ei onnellinen }(3,4 \& 5)\end{array}$ \\
\hline $\begin{array}{l}\text { Olen sukupuolisesti puoleensavetävä? } \\
\text { Oletteko koskaan ollut sukupuoliyhdynnässä? }\end{array}$ & $\begin{array}{l}1-5, \\
1=\text { täysin samaa mieltä, } \\
5=\text { täysin eri mieltä } \\
1=\text { kyllä, } 2=\text { ei }\end{array}$ & $\begin{array}{l}\text { 1 = hyvin tai melko yksinäinen } \\
(1 \& 2), 2 \text { = Vähän yksinäinen } \\
(3), 3=\text { Ei lainkaan yksinäinen } \\
(4) \\
1=\text { samaa mieltä }(1 \& 2), \\
2=\text { eri mieltä }(4,5), \\
3=\text { ei samaa eikä eri mieltä }\end{array}$ \\
\hline $\begin{array}{l}\text { Kun arvioitte omaa sukupuolielämäänne kokonaisuutena katsottuna, niin } \\
\text { pidättekö sitä: }\end{array}$ & $\begin{array}{l}1-5, \\
1=\text { hyvin tyydyttävänä, } \\
5=\text { hyvin epätyydyttävänä }\end{array}$ & $\begin{array}{l}1 \text { = tyydyttävä }(1 \& 2) \\
2=\text { vaikea sanoa }(3) \\
3=\text { epätyydyttävä }(4 \& 5)\end{array}$ \\
\hline $\begin{array}{l}\text { Jos olette ollut sellaisessa tilanteessa, että olette kaivannut } \\
\text { sukupuolikumppania, onko kumppanin löytyminen ollut Teille: }\end{array}$ & $\begin{array}{l}1=\text { erittäin vaikeaa, } 2=\text { melko vaikeaa, } 3=\text { ei } \\
\text { vaikeaa eikä helppoa, } 4=\text { melko helppoa, } 5= \\
\text { täysin helppoa, } 6=\text { en ole kaivannut } \\
\text { sukupuolikumppania }\end{array}$ & $\begin{array}{l}1=\text { vaikeaa }(1 \& 2) \\
2=\text { ei helppoa eikä vaikeaa } \\
(3), 3=\text { helppoa }(4 \& 5) \\
4=\text { En ole kaivannut } \\
\text { sukupuoikumppania (6) }\end{array}$ \\
\hline Onko olemassa joku, joka rakastaa sinua? & $\begin{array}{l}1=\text { kyllä, } 2=e \mathrm{i}, 3=\text { en osaa sanoa (vaihtoehto } \\
\text { vuonna 1992) }\end{array}$ & \\
\hline Terveys ja elintavat & & \\
\hline $\begin{array}{l}\text { Onko teillä viimeisen kuukauden aikana esiintynyt a) unettomuutta, b) pääns } \\
\text { d) ylirasittuneisuutta, e) yleistä väsymystä tai heikkouden tunnetta, f) h } \\
\text { i) kuumotusta } \quad \text { tai hikoilua } \quad \text { ilman } \\
\text { (Tarkastelussa käytetyssä summamuuttujassa esiintyvyyksien arvot on laskett }\end{array}$ & $\begin{array}{l}\text { ärkyä, c) jännittyneisyyttä tai ahdistuneisuutta, } \\
\text { uimausta, g) painajaisunia, h) käsien vapinaa, } \\
\text { ruumiillistararar } \\
\text { u yhteen) }\end{array}$ & $\begin{array}{l}1=\text { ei juuri lainkaan } \\
2=\text { joskus } \\
3=\text { usein }\end{array}$ \\
\hline $\begin{array}{l}\text { Kuinka usein harrastatte liikuntaa, jonka tarkoituksena on fyysisen kuntonne } \\
\text { kohottaminen tai ylläpitäminen, vähintään puoli tuntia kerrallaan? }\end{array}$ & $\begin{array}{l}\text { 1) päivittäin, 2) } 2-3 \text { kertaa viikossa, 3) kerran } \\
\text { viikossa, 4) } 2-3 \text { kertaa kuussa } \\
\text { 5) muutaman kerran vuodessa, 6) En koskaan, } \\
\text { 7) En voi vaman tai sairauden takia harrastaa }\end{array}$ & $\begin{array}{l}1=\text { ainakin kaksi kertaa } \\
\text { viikossa }(1 \& 2), 2=2-4 \text { kertaa } \\
\text { kuukaudessa }(3 \& 4), 3= \\
\text { maksimissaan muutaman }\end{array}$ \\
\hline Katsotteko uskonnon elämässänne? & 1-4, 1 = hyvin tärkeä, 4 = ei lainkaan tärkeä & $\begin{array}{l}1 \text { = hyvin tärkeä (1), } \\
2=\text { tärkeä }(2), \\
3=\text { ei tärkeä }(3 \& 4)\end{array}$ \\
\hline Kuinka usein käytätte alkoholia tosi humalaan asti? & $\begin{array}{l}1=\text { vähintään kerran viikossa, } 2=\text { Pari kertaa } \\
\text { viikossa, } 3=\text { Kerran viikossa, } 4=\text { Pari kertaa } \\
\text { kuukaudessa, } 5=\text { Noin kerran kuukaudessa, } \\
6=\text { Noin kerran kahdessa kuukaudessa, } \\
7=3-4 \text { kertaa vuodessa, } 8=\text { Kerran vuodessa } \\
\text { tai harvemmin, } 9=\text { En lainkaan }\end{array}$ & $\begin{array}{l}1=\text { vähintään pari kertaa } \\
\text { viikossa }(1 \& 2), \\
2=1-4 \text { kertaa kk }(3,4,5), \\
3=\text { harvemmin kuin kerran } \\
\text { kuussa }(6,7,8), \\
4=\text { En lainkaan (9) }\end{array}$ \\
\hline Oleteko tällä hetkellä? & $\begin{array}{l}1=\text { palkansaaja kokopäiväisesti, } \\
2=\text { palkansaaja osapäivätoimisesti, } \\
3=\text { maatalousyrittäjä, työssä perheen } \\
\text { maatilalla, } 4=\text { muu yrittäjä, } 5=\text { työtön tai } \\
\text { lomautettu ilman palkka, } 6=\text { eläkkeellä, } \\
7=\text { opiskelija, } 8=\text { hoidatte kotia, } 9=\text { muu } \\
\text { vaihtoehto }\end{array}$ & $\begin{array}{l}1 \text { = työtön (5), } \\
2=\text { töissä tai opikeljija } \\
(1,2,3,4,7) \\
3=\text { eläkkeellä }(6) \\
4 \text { = muu }(8,9)\end{array}$ \\
\hline Kuinka suuret ovat tulonne kuukaudessa, kun verot on vähennetty? & $\begin{array}{l}\text { 1-10, keräyskerroittain vaihtuvat viralliset } \\
\text { väestön tulokymmenykset }\end{array}$ & $\begin{array}{l}\text { 1-5, keräyskerroittain vaihtuvat } \\
\text { viralliset väestön tulokvintiilit, } \\
\text { tulokymmenykset yhdistetty } \\
\text { kvintiileiksi } 1 \text { 1) } 1 \& 2 \text {, alle } \\
600 € / \text { kk 2) } 3 \& 4,601-1050 \\
€ / \text { kk 3) } 5 \& 6,1051-1450 € / \text { kk } \\
\text { 4) } 7 \& 8,1451-1850 € / \text { kk } \\
\text { 5) } 9 \& 10 \text { yli } 1851 € / \text { kk }\end{array}$ \\
\hline
\end{tabular}

